\title{
PENGARUH PERSEPSI MASYARAKAT TERHADAP PENGEMBANGAN DESA WISATA CIBURIAL KABUPATEN BANDUNG
}

\author{
Anggi Ratna Juwita ${ }^{1}$ \\ Universitas Pendidikan Indonesia. \\ anggiejuwita14@gmail.com \\ Fitri Rahmafitria ${ }^{2}$ \\ Universitas Pendidikan Indonesia. \\ rahmafitria@upi.edu \\ Rosita $^{3}$ \\ Universitas Pendidikan Indonesia. \\ Rosita@upi.edu
}

\begin{abstract}
ABSTRAK
Penelitian ini bertujuan untuk mengidentifikasi persepsi masyarakat yang berdomisili di sekitar Desa Wisata Ciburial mengenai keberadaan desa sebagai desa wisata dan keberadaan daya tarik disekitar desa. Selain itu, penelitian ini juga bertujuan untuk mengidentifikasi partisipasi masyarakat Desa Ciburial terhadap kegiatan wisata yang terjadi di kawasan Desa Wisata Ciburial serta menganalisis bagaimana pengaruh persepsi tersebut terhadap partisipasi masyarakat di Desa Wisata Ciburial. Dalam penelitian ini metode yang digunakan adalah metode analisis regresi sederhana dengan menjadikan masyarakat Desa Ciburial sebanyak seratus orang sebagai sampel dalam penelitian ini. Hasil penelitian, menemukan bahwa program pengembangan tidak akan berjalan baik jika masyarakat belum memahami apa itu desa wisata. Masyarakat diharapkan dapat lebih kreatif dalam melakukan inovasi dan memanfaatkan hasil bumi serta kreatifitas masyarakat khas Desa Ciburial agar Desa Wisata Ciburial dapat dipilih karena memiliki ciri khas dan dapat memberikan dampak positif terhadap masyarakat.
\end{abstract}

Kata Kunci: Persepsi, Partisipasi, Masyarakat, Desa Wisata 


\section{THE INFLUENCE OF PERCEPTION TO THE SOCIETY PARTICIPATION IN DEVELOPING CIBURIAL TOURISM VILLAGE KABUPATEN BANDUNG}

This study aims to identify the perception of the people who live around Ciburial Tourism Village about the existence of the village as a tourism village and the existence of appeal around the village. In addition, this study also aims to identify Ciburial village's community participation to tourist activities occurring in the Ciburial Tourism Village and to analyze how these influences perception of people's participation in the Tourism Village Ciburial. In this research method used is simple regression analysis method by making hundred people as a sample in this study. From these results can be expected by society more aware of the tourist village and tourist village for development program will not run properly if people do not understand that tourist village. We must be aware of the existence of tourism that will provide a significant impact to the lives of villagers especially the Village Ciburial. Society is expected to be more creative in innovating and utilizing resources and people's creativity that is originally from Ciburial Tourism Village that can be selected for has distinctive features and can give a positive impact to the society.

Keywords: Perception, Participation, Society, and Tourism Village.

\section{PENDAHULUAN}

Bandung adalah kota terbesar di Jawa barat sekaligus menjadi ibu kota provinsi. Kota ini memiliki banyak potensi alam dan budaya, sejak dibukanya jalan tol Cipularang, Kota Bandung telah menjadi tujuan utama dalam menikmati liburan terutama masyarakat yang berasal dari Jakarta dan sekitarnya, selain dikenal dengan wisata alam, budaya dan belanja, Bandung juga dikenal dengan wisata sejarah kerena terdapat bangunan-bangunan lama peninggalan Belanda yang berada di kota maupun kabupaten. Dengan banyaknya karakteristik tempat seperti desa-desa yang unik di Bandung, menjadi salah satu alasan maraknya kegiatan wisata yang mengangkat tema desa dengan berbagai keunikannya. Masyarakat kota yang telah jenuh dengan suasana perkotaan pasti akan lebih memilih untuk tinggal di homestay yang berada di desa-desa dibandingkan menginap di hotel, maka dari itu dewasa ini semakin banyak wisata-wisata yang mengangkat desa wisata sebagai daya tarik. Salah satu desa wisata di Indonesia tepatnya di Jawa Barat yang bisa menjadi alternatif tujuan wisata adalah Desa Ciburial Kabupaten Bandung Provinsi Jawa Barat. Desa Wisata Ciburial memiliki berbagai usaha rumahan seperti kerajinan tangan, tempat pelatihan budidaya lebah madu Cikaturug, peternakan sapi dan beberapa sanggar kebudayaan lengkap dengan komunitas seni didalamnya turut mendukung keberlangsungan kegiatan para wisatawan selama berada di Desa Wisata Ciburial sehingga dapat di kategorikan jenis desa ini adalah Desa Agroekowisata. Berikut adalah data kunjungan wisatawan yang berkunjung ke Desa Wisata Ciburial: 


\begin{tabular}{cc}
\hline Tahun & Jumlah Kunjungan Wisata \\
\hline $\mathbf{2 0 0 8}$ & 226.057 \\
$\mathbf{2 0 0 9}$ & 240.629 \\
$\mathbf{2 0 1 0}$ & 247.426 \\
$\mathbf{2 0 1 1}$ & 305.054 \\
$\mathbf{2 0 1 2}$ & 307.244 \\
$\mathbf{2 0 1 3}$ & 304.977 \\
$\mathbf{2 0 1 4}$ & 483.068 \\
\hline
\end{tabular}

Sumber : Desa Ciburial 2014

Dilihat dari data kunjungan di atas, dengan jumlah wisatawan yang terus meningkat dari tahun ke tahun dan terbilang cukup banyak serta beberapa potensi yang dimiliki desa wisata ini menjadikan desa ini dipilih sebagai 10 desa wisata di Jawa Barat. Akan tetapi, dalam pengembangannya Desa Wisata Ciburial masih mengalami beberapa kendala. Salah satunya adalah kurangnya sumber daya manusia yang mengerti akan pariwisata. Kesadaran masyarakat terhadap pariwisata dan perubahan yang terjadi di Desa Wisata Ciburial ini pun masih sangat kurang, dimana rata-rata dari penduduk lokal tidak begitu sadar dan merasakan dampak dari berkembangnya Desa Ciburial menjadi sebuah desa wisata.

Masyarakat masih belum memahami definisi desa wisata, keikutsertaan atau partisipasi masyarakat dalam mengelola dan mengembangkan desa wisata pun sangat kecil. Persepsi masyarakat yang tidak benar mengenai desa wisata akan menghasilkan dampak negatif bagi keberlangsungan Desa Wisata Ciburial, tapi sebaliknya jika persepsi masyarakat benar mengenai keberadaan Desa Ciburial sebagai desa wisata maka akan menghasilkan dampak positif bagi pengembangan desa wisata tersebut.

Tujuan dari penelitian ini yaitu Mengidentifikasi persepsi masyarakat mengenai keberadaan desa wisata dan daya Tarik apa saja yang ada di Desa Ciburial. Serta menganalisis pengaruh persepsi terhadap partisipasi masyarakat mengenai keberadaan Desa Wisata Ciburial. Sehingga hasil dari penelitian ini dapat dipakai sebagai acuan untuk pengelola dan masyarakat desa untuk mengembangkan desa wisata ini ke arah yang lebih baik.

\section{METODOLOGI}

Penelitian ini dilaksanakan di desa Ciburial Kabupaten Bandung dengan jumlah penduduk sekitar 12.034 orang. Pengumpulan data dalam penelitian ini yaitu menggunakan data primer seperti wawancara dan kuesioner lalu menggunakan data sekunder seperti studi literatur, data dari desa dan pencarian dari internet. Metode yang digunakan peneliti dalam penelitin ini adalah analisis 
deskriptif dengan pendekatan kuantitatif. Yang menjadi populasi pada penelitian ini adalah masyarakat Desa Ciburial, berdasarkan data monograf dari Desa Ciburial yaitu sebanyak 12.034 dengan jumlah laki-laki sebanyak 6.298 dan perempuan sebanyak 5.736 orang. Penelitian ini mempunyai mempunyai persentase error dengan batas kesalahan $10 \%$ dengan perhitungan: $n=\mathrm{N} /\left(1+\mathrm{N} \mathrm{e}^{2}\right)=12.034 /\left(1+12.034 \times 0,1^{2}\right)=99,45=99,5$

Dengan demikian, sampel yang digunakan untuk penelitian adalah 100 dari populasi. Kemudian setelah sampel kuesioner itu terkumpul dan dihitung berdasarkan skala likert maka penulis akan mengkonversikan data tersebut kedalam metode MSI, karena skala likert adalah data ordinal sedangkan analisis data menggunakan regresi linier sederhana membutuhkan data interval. Maka perlu mengkonversikan data ordinal menjadi interval caranya adalah menggunakan Method Of Successive Interval (MSI). Setelah itu akan diuji menggunakan uji validitas dan reliabilitas. Perhitungan validitas dan reliabilitas instrumen dilakukan dengan bantuan software IBM SPSS Statistics 20 for Windows. Uji selanjutnya yang di gunakan yaitu uji asumsi klasik regresi sederhana, diantaranya yaitu uji normalitas, uji heretoskedastisitas, uji multikolonieritas, uji autokorelasi dan regresi sederhana dan akan di bagi menjadi uji determinasi dan uji hipotesis untuk mengetahui seberapa besar pengaruh persepsi masyarakat $(\mathrm{x})$ terhadap partisipasi $(\mathrm{y})$.

\section{HASIL DAN PEMBAHASAN}

Desa Ciburial terletak di Kecamatan Cimenyan, Kabupaten Bandung. Desa ini memiliki luas wilayah 599,612 ha. Desa Wisata Ciburial sendiri merupakan desa yang berada di dataran tinggi Kabupaten Bandung yang lokasinya dapat terhubung langsung dengan kawasan Bandung Timur dan Kabupaten Bandung Barat.

Dilihat dari kondisi iklim Desa Ciburial, daerah ini memiliki iklim sedang dimana ketinggian antara $600-1500 \mathrm{~m}$ dpl dengan suhu rata-rata $22^{\circ} \mathrm{C}$, sehingga daerah ini masih cocok ditanami jenis sayuran, tembakau, kopi dan lain sebagainya. Desa Wisata Ciburial adalah satu dari sepuluh desa yang dikembangkan menjadi desa wisata oleh pemerintah Kabupaten Bandung terpilih dan dinyatakan sebagai desa wisata secara resmi pada tahun 2011. Desa Ciburial terpilih karena dianggap memiliki cukup potensi dan mampu bersaing dengan desa-desa wisata lainnya yang ada di Indonesia khususnya di Jawa Barat.

Desa Ciburial adalah salah satu desa di Kecamatan Cimenyan, desa yang berada di paling Utara Kabupaten Bandung ini memiliki jumlah penduduk 12.034 orang dengan perbandingan laki-laki 6.298 orang dan perempuan berjumlah 5.736 orang. Kepadatannya yaitu sekitar 1700/km. Jumlah kepala keluarga di Desa Ciburial adalah 3.529 kk. Wilayah Desa Ciburial terdiri dari tiga dusun atau desa, 51 unit RT serta 12 unit Rw. Agama yang di anut di dominasi oleh islam yaitu sekitar 11.883 orang dan Kristen sebanyak 151 orang.

Cara hidup penduduk di Ciburial termasuk beragam dimana banyak penduduk yang sudah hidup dengan cara yang lebih modern, hidup masing- 
masing dan menjadikan Desa Ciburial hanya sebatas tempat singgah saja. Ada pula yang hidup masih dengan nuansa desa, kekeluargaan dan cenderung lebih sering berkumpul hanya untuk mengobrol. Di wilayah yang cenderung lebih maju yaitu disekitar kantor desa kehidupan masyarakat pedesaan sudah sangat sulit ditemukan, masyarakat cenderung lebih acuh dan sudah seperti masyarakat kota pada umumnya. Berbeda dengan masyarakat yang tinggal di dataran yang lebih tinggi, kehidupan bermasyarakat masih sangat dipertahankan, rata-rata masyarakat lokal ramah kepada para pendtang. Begitu pun dengan pola usaha yang dijalankan, jika masyarakat yang tinggal disekitar kantor desa cenderung memiliki pola usaha yang lebih modern seperti bekerja dikantor dan di kafe-kafe yang ada di sekitar desa. Beberapa warga memiliki peternakan sapi dan lebah madu, beternak, bertani, sebagian dari mereka membuka usaha warung bandrek dan beberapa menjadi tukang ojek dadakan untuk menuju ke Tebing Keraton.

Lembaga masyarakat yang ada di desa sendiri cenderung kurang berintegrasi dengan masyarakat dan belum memfasilitasi masyarakat secara keseluruhan. Terlihat dari segala jenis pengembangan desa yang dilakukan secara tidak merata.

Berikut ini merupakan beberapa profil dari masyarakat di Desa Ciburial, yang tentunya berkaitan dengan keberadaan pariwisata. Profil masyarakat merupakan data masyarakat yang berada di Desa Ciburial. Untuk mengetahui data masyarakat maka dilakukan penyebaran kuesioner kepada 100 orang responden sebagai sampel dari penelitian sehingga dapat diketahui karakteristik masyarakat yang ada di Desa Ciburial. Profil wisatawan akan dibagi ke dalam lima pertanyaan, yaitu jenis kelamin, usia, pendidikan terkahir, pekerjaan dan pendapatan.

Profil masyarakat berdasarkan jenis kelamin di Desa Ciburial yaitu penduduk laki-laki lebih banyak dibandingkan perempuan dengan selisih angka yaitu 562 orang. Angket yang di sebar oleh peneliti juga menunjukan bahwa responden laki-laki lebih banyak dibandingkan perempuan yaitu sebesar 58\% dan perempuan sebanyak $42 \%$. Berdasarkan data yang di dapat peneliti, yaitu sekitar 8.274 penduduk Desa Ciburial berada di usia produktif yaitu 19 tahun ke atas. Lalu bayi berusia 0-3 tahun sekitar 612 orang, 4-6 tahun sekitar 790 orang, 7-12 tahun 1.573 orang. Berdasarkan data yang ada di Desa Ciburial, sekitar 6.276 orang masyarakat adalah lulusan Sekolah Dasar sedangkan SMP/SLTP yaitu sekitar 1.988 kemudian SMA/SLTA yaitu 1532 orang. Dan yang lulusan D1-D3 sekitar 296 orang dan yang sarjana atau S1 yaitu 301 orang. Dari data tersebut bisa dilihat bahwa jumlah masyarakat yang didominasi oleh masyarakat berpendidikan terakhir SD/Sederajat, menunjukan bahwa tingkat pendidikan masyarakat Desa Ciburial masih rendah. Dilihat dari beberapa warga masyarakat di sekitar desa tidak terlalu peduli akan berkembangnya desa menjadi desa wisata karena tidak banyak yang berubah dari berkembangnya desa. Dari kuisioner yang dibagikan kepada warga, dapat dilihat bahwa kebanyakan mereka yang mengisi adalah tamatan SMA yaitu sekitar 50\% dari seluruh kuisioner, ini dilakukan untuk memudahkan penulis untuk mendapatkan respon yang kritis untuk setiap pertanyaan. 
Data yang di dapat diketahui yaitu sekitar 15\% warga masyarakat berpenghasilan Rp. 500.000-1.000.000 sedangkan sekitar 18\% warga yang penghasilanya Rp. 1.000.000-1.500.000 dan yang paling tinggi yaitu di rentang Rp. 1.500.000-2.000.000 yaitu sekitar 45\% dari kuisioner. Yang terakhir yaitu penghasilan di atas Rp.2.000.000 hal ini terjadi karena kebanyakan warga masyarakat yang ada di Ciburial mata pencaharianya yaitu bertani dan buruh tani sehingga penghasilan yang di dapat tidak menentu dan yang paling mendekati dengan penghasilan mereka adalah di rentang Rp.1.000.000 sampai Rp.2.000.000. dilihat dari data tersebut masih dirasa kurang untuk penghasilan warga masyarakat yang di dominasi oleh petani. Dampak pariwisata yang ada hanya mampu untuk memperkerjakan masyarakat di restoran atau café-café sedangkan untuk mengelola homestay ataupun kerajinan tangan masih kurang.

Data yang didapat diketahui bahwa mata pencaharian yang mandominasi kuisioner adalah petani yaitu di angka $27 \%$ atau 27 orang hal ini sangat sesuai dilihat dari masih banyaknya perkebunan milik warga yang masih terjaga kelestarianya. Bukan hanya petani saja yang ada di Desa Ciburial ini tetapi banyak juga buruh tani yang memelihara lahan milik swasta. Kemudian warga masyarakat yang mata pencahariannya yaitu wiraswasta dan pegawai swasta yaitu di rentang $25 \%$ karena banyak pegawai pegawai swasta seperti menjadi staf di salah satu restoran atau café-café yang berjamur di daerah Ciburial. Dan banyak juga dari meraka yang memiliki usaha sendiri seperti warung-warung kecil dan lain sebagainya. Berdasarkan data yang di dapat pun menunjukan bahwa sekitar 936 orang bermata pencaharian sebagai petani dan 286 orang adalah buruh tani, lalu pegawai swasta sekitar 813 orang disusul 318 orang yang berdagang atau wiraswasta kemudian sekitar 202 orang yaitu Pegawai Negri Sipil lalu ada 4 orang ABRI dan sisanya belum bekerja. Dapat dilihat dari data tersebut menunjukan bahwa keragaman mata pencaharian pokok baru bagi masyarakat tentunya dalam bidang-bidang yang terkait dengan sektor pariwisata masih dirasa kurang, dilihat dari masih banyaknya warga masyarakat yang mata pencahariannya sebagai petani.

\section{Persepsi Masyarakat dalam Program Pengembangan Desa Wisata di Ciburial}

Berdasarkan hasil garis kontinum mengenai persepsi masyarakat terkait mata pencaharian masih mencerminkan kehidupan sosial ekonomi pedesaan diperoleh total skor 417 atau 83,4\% dan termasuk kedalam kategori tinggi. Persepsi masyarakat Desa Wisata Ciburial terhadap melestarikan mata pencaharian yang masih tradisional sangat mendukung seperti pertanian, perkebunan peternakan dll. Jika dilihat dari profil masyarakat yang dominan adalah petani baik sebagai pemilik lahan, buruh tani atau keduanya. Maka dari itu, keadaan alam yang ada di desa ini harus dilestarikan karena lahan pertanian harus melihat kadar air, tanah cuaca dan udara. Sehingga masyarakat masih tetap bisa melestarikan mata penchariannya. Selain mata pencaharian bertani, di desa ini juga terdapat peternakan lebah madu yang terkenal yaitu madu Cikaturug, masyarakat juga berharap peternakan lebah ini bisa terus bertahan. Mengingat 
Desa Wisata Ciburial dijadikan desa wisata oleh pemerintah dikarenakan banyaknya lahan-lahan pertanian dan usaha peternakan, maka dari itu desa wisata ini dikenal sebagai Desa Agroekowisata.

Pertanyaan mengenai desa wisata dapat menambah mata pencaharian masyarakat tinggi yaitu dengan skor 413 atau 82,6\%. Artinya masyarakat setuju jika adanya pariwisata berdampak pada mata pencaharian di Desa Wisata Ciburial. Jika dilihat dari profil jenis pekerjaan, pegawai swasta berada di urutan kedua dengan skor sama dengan wiraswasta, jika dilihat dari hasil wawancara, Perubahan signifikan yang dirasakan langsung oleh masyarakat yaitu ketersediaan lahan pekerjaan yang sekarang lebih beragam karena banyak dibangun kafe-kafe disekitar desa dan aksesibilitas menuju desa yang terus diperbaiki

Banyak warga yang bekerja di café-café ataupun mereka membuat usaha dagang seperti warung. Bahkan di area-area parkir seperti Tahura, Tebing Keraton dan tempat wisata lainnya kita pasti melihat bahwa tukang parkir yang bekerja disana adalah warga masyarakat sekitar. Tetapi ada juga warga yang acuh atau tidak begitu peduli terhadap perkembangan desa wisata ini karena tempattempat wisata di Desa Wisata Ciburial yang telah berjalan lebih awal menjadi alasan mengapa perubahan desa menjadi desa wisata dirasa tidak terlalu berdampak, karena pengelola tempat wisata yang telah berjalan lebih awal tersebut cenderung merasa dengan diubahnya desa menjadi desa wisatapun tidak banyak yang berubah pada penghasilan yang didapatkan sehingga banyaknya wisatawan yang datang ke tempat wisata tersebut dianggap bukan dampak langsung dari desa wisata.

Persepsi selanjutnya mengenai adat dan norma ialah masyarakat setuju jika adanya pariwisata tidak menjadikan desa mereka berubah untuk tatanan adat, norma dan nilai yang masih mencerminkan tradisi lokal masyarakat desa. Ketersediaan lahan dan suburnya tanah menjadi salah satu alasan banyak ditemukan lahan pertanian disini (RW 09 dan 10). Di RW 09 dan 10 ini keadaan alamnya cenderung lebih alami dan bahkan tidak terlihat modernisasi, jenis bangunan dan cara hidup masyarakat disekitar RW 09 dan 10 pun masih cenderung tradisional. Warga masyarakat yang masih ramah mencerminkan bahwa tidak ada yang berubah untuk nilai adat dan norma di Desa Wisata Ciburial ini.

Kehidupan sosial budaya pedesaan pun dapat dilihat dari kegiatan kesenian yang masih di lestarikan seperti terdapat sekitar RW 10 terdapat beberapa komunitas seni, seperti komunitas karinding yang bertujuan melestarikan Artinya masyarakat setuju jika karakter dan budaya lokal masyarakat desa masih mencerminkan alat musik karinding. Hanya saja seiring berjalannya waktu komunitas-komunitas seni tersebut semakin jarang melakukan perkumpulan. Rata-rata dari komunitas seni tersebut hanya latihan atau berkumpul ketika akan diadakannya event-event besar, seperti festival tahunan yang biasa diadakan di Desa Wisata Ciburial yaitu CIFEST atau Ciburial Festival. 
Masyarakat juga setuju bahwa Setelah adanya desa wisata kegiatan keseharian masyarakat masih mencerminkan kehidupan masyarakat pedesaan. Tapi Jika dilihat cara hidup penduduk di Desa Wisata Ciburial termasuk beragam dimana banyak penduduk yang sudah hidup dengan cara yang lebih modern, hidup masing-masing dan menjadikan Desa Ciburial hanya sebatas tempat singgah saja. Ada pula yang hidup masih dengan nuansa desa, kekeluargaan dan cenderung lebih sering berkumpul hanya untuk mengobrol. Di wilayah yang cenderung lebih maju yaitu disekitar kantor desa kehidupan masyarakat pedesaan sudah sangat sulit ditemukan, masyarakat cenderung lebih acuh dan sudah seperti masyarakat kota pada umumnya.

Berbeda dengan masyarakat yang tinggal di dataran yang lebih tinggi, kehidupan bermasyarakat masih sangat dipertahankan, rata-rata masyarakat lokal pun terbilang sangat ramah. Begitu pun dengan pola usaha yang dijalankan, jika masyarakat yang tinggal disekitar kantor desa cenderung memiliki pola usaha yang lebih modern seperti bekerja dikantor dan di kafe-kafe yang ada disekitar desa dan beberapa saja memiliki peternakan sapi dan lebah madu, masyarakat yang tinggalnya cukup jauh dari kantor desa memiliki pola usaha yang lebih mencirikan bahwa mereka orang desa, seperti beternak, bertani, sebagian dari mereka membuka usaha warung bandrek dan beberapa menjadi tukang ojek dadakan untuk menuju ke Tebing Keraton.

Desa wisata juga dapat membantu mempelajari lintas budaya yang dibawa oleh wisatawan. Banyaknya wisatawan yang masuk ke kawasan wisata Ciburial menjadikan warga masyarakat sedikit-sedikit mempelajari budaya wisatawan yang masyarkat lihat. Karena, wisatawan yang datang tidak hanya warga Jawa Barat saja melainkan banyak warga masyarakat dari luar pulau membawa kebudayaan mereka ke Desa Wisata Ciburial. Mereka juga melihat cara berpakaian wisatawan, cara berbicara dan lain sebagainnya.

\section{Hasil Rekapitulasi Persepsi Masyarakat dalam Program Pengembangan Desa Wisata Ciburial}

\begin{tabular}{llcc}
\hline No & \multicolumn{1}{c}{ Pernyataan } & $\begin{array}{c}\text { Skor } \\
\text { Total }\end{array}$ & Kategori \\
\hline 1. & $\begin{array}{l}\text { Mata pencaharian masyarakat desa masih mencerminkan kehidupan } \\
\text { sosial ekonomi pedesaan }\end{array}$ & 417 & Tinggi \\
2. $\quad \begin{array}{l}\text { Kegiatan desa wisata dapat meningkatkan pendapatan masyarakat desa } \\
\text { 3. }\end{array} \quad 413$ & Tinggi \\
4. $\quad \begin{array}{l}\text { Adat, norma dan nilai yang berlaku di desa wisata masih } \\
\text { mencermminkan tradisi lokal masyarakat desa }\end{array}$ & 398 & Tinggi \\
5. $\quad \begin{array}{l}\text { Karakter dan budaya lokal masyarakat desa wisata masih mencerminkan } \\
\text { kehidupan sosial budaya pedesaan }\end{array}$ & 399 & Tinggi \\
6. $\quad$ Desa wisata dapat memelihara keberadaan budaya lokal & 391 & Tinggi \\
\hline
\end{tabular}




\begin{tabular}{|c|c|c|c|}
\hline 7. & $\begin{array}{l}\text { Kegiatan keseharian masyarakat desa wisata masih mencerminkan } \\
\text { kehidupan masyarakat pedesaan }\end{array}$ & 393 & Tinggi \\
\hline 8. & $\begin{array}{l}\text { Desa wisata dapat membantu mempelajari lintas budaya yang dibawa } \\
\text { oleh wisatawan }\end{array}$ & 406 & Tinggi \\
\hline 9. & $\begin{array}{l}\text { Desa wisata dapat menumbuhkan rasa hormat terhadap perbedaan dan } \\
\text { kehormatan manusia }\end{array}$ & 411 & Tinggi \\
\hline 10. & Bangunan yang ada di desa wisata masih berasitektur tradisional & 410 & Tinggi \\
\hline 11. & $\begin{array}{l}\text { Struktur tata ruang di desa wisata masih mencerminkan ciri khas } \\
\text { pedesaan }\end{array}$ & 399 & Tinggi \\
\hline 12. & $\begin{array}{l}\text { Kegiatan perekonomian yang dilakukan masih mencerminkan kegiatan } \\
\text { ekonomi masyarakat pedesaan }\end{array}$ & 391 & Tinggi \\
\hline 13. & $\begin{array}{l}\text { Atraksi yang ditawarkan terkait dengan kegiatan masyarakat desa } \\
\text { seperti bertani, bercocok tanam dan beternak }\end{array}$ & 393 & Tinggi \\
\hline 14 & $\begin{array}{l}\text { Atraksi atau kegiatan yang ditawarkan di desa wisata harus melibatkan } \\
\text { masyarakat desa }\end{array}$ & 406 & Tinggi \\
\hline 15 & $\begin{array}{l}\text { Akomodasi (tempat menginap) berupa homestay milik warga Desa } \\
\text { Wisata Ciburial. }\end{array}$ & 411 & Tinggi \\
\hline \multirow[t]{2}{*}{16} & $\begin{array}{l}\text { Makanan dan minuman (kuliner) harus sesuai dengan ciri khas desa } \\
\text { wisata }\end{array}$ & 410 & Tinggi \\
\hline & $\begin{array}{c}\text { Jumlah Skor } \\
\text { Jumlah Persentase }\end{array}$ & $\begin{array}{l}6.448 \\
80,6 \%\end{array}$ & Tinggi \\
\hline
\end{tabular}

Sumber : data diolah peneliti (2016)

Berdasarkan table diatas mengenai hasil rekapitulasi persepsi masyarakat dalam program pengembangan desa wisata, skor tertinggi diperoleh dari pernyataan mata pencaharian msyarakat desa masih mencerminkan kehidupan sosial ekonomi pedesaan yaitu sebesar 417, sedangkan skor terendah diperoleh dari pernyataan keberadaan desa wisata data memelihara keberadaan budaya lokal yaitu sebesar 391. Dengan demikian, total skor yang diperoleh dari 16 pernyataan mengenai persepsi masyarakat dalam program pengembangan desa wisata yaitu sebesar 6448, yang dimana pada garis kontinum menunjukan dalam kategori baik dan berada pada rentang nilai antara 5440-6720.

Dari hasil tersebut dapat disimpulkan bahwa persepsi masyarakat dalam program pengembangan desa wisata masuk dalam kategori tinggi. Dari setiap pernyataan terkait persepsi masyarakat dalam program pengembangan desa wisata masuk kedalam kategori baik artinya persepsi masyarakat Desa Wisata Ciburial dalam program pengembangan desa wisata itu baik. Persepsi dan partisipasi tinggi karena sering di adakannya penyuluhan terkait pariwisata sebagai contoh penyuluhan oleh mojang jajaka Kabupaten Bandung.

\section{Partisipasi Masyarakat dalam Program Pengembangan Desa Wisata Ciburial}

Dalam penelitian ini, partisipasi masyarakat dalam program pengembangan desa wisata merupakan variabel. Partisipasi masyarakat menurut : Ericson (dalam Slamet, 1994,hlm.89)

1. Partisipasi di dalam tahap perencanaan

2. Partisipasi dalam tahap pelaksanaan

3. Partisipasi didalam tahap pemanfaatan atau evaluasi 
Pada sub variabel partisipasi dalam tahap perencanaan terdapat lima indikator yaitu masyarakat ikut terlibat dalam perencanaan seperti mengikuti rapat, masyarakat ikut berpartisiasi dalam proses pengambilan keputusan, masyarakat dilibatkan dalam proses pembangunan sarana dan prasarana desa, masyarakat ikut berpartisipasi dalam program kebersihan desa dan ikut berpartisipasi dalam pertemuan yang di adakan di Desa Ciburial

Sedangkan pada sub variabel partisipasi dalam pengambilan keputusan terdapat tiga indikator yaitu masyarakat ikut terlibat dalam program pelatihan kerajinan tangan di desa wisata, masyarakat ikut berpartisipasi dalam melestarikan dan mengajarkan kesenian tradisional yang ada di desa wisata. Masyarakat ikut berpartisipasi dalam kegiatan atraksi wisata.

Yang terakhir ialah sub variabel partisipasi dalam pemanfaatan hasil terdapat dua indikator yaitu masyarakat ikut serta menyumbangkan tenaga dan materi untuk kegiatan pengembangan desa wisata dan masyarakat ikut berpartisipasi dalam mengamankan wilayah desa wisata.

\section{Rekapitulasi Partisipasi Masyarakat dalam Program Pengembangan Desa Wisata di Ciburial

\begin{tabular}{clc}
\hline No & \multicolumn{1}{c}{ Sub Variabel } & Skor \\
\hline 1. & $\begin{array}{l}\text { Partisipasi dalam tahap } \\
\text { prencanaan }\end{array}$ & $\mathbf{1 8 2 5}$ \\
2. & Partisipasi dalam Pelaksanaan & $\mathbf{1 0 0 7}$ \\
3. & $\begin{array}{l}\text { Partisipasi dalam Pemanfaatan } \\
\text { Hasil dan evaluasi }\end{array}$ & $\mathbf{7 0 0}$ \\
& $\quad$ Jumlah Skor & $\mathbf{3 5 3 2}$ \\
& Presentase Skor & $\mathbf{7 0 , 6 4 \%}$ \\
\hline
\end{tabular}

Sumber : data diolah peneliti (2016)

Berdasarkan tabel mengenai rekapitulasi tanggapan responden mengenai partisipasi masyarakat dalam program pengembangan desa wisata skor tertinggi diperoleh dari sub variabel "partisipasi dalam perencanaan program pengembangan desa wisata " yaitu sebesar 1825, sedangkan skor terendah di peroleh dengan sub variable partisipasi dalam pemanfaatan hasil dan evaluasi pengembangan desa wisata yaitu hanya sebesar 700. Dengan demikian skor total yang di peroleh dari tiga sub variabel mengenai partisipasi masyarakat dalam program pengembangan Desa Wisata di Ciburial adalah sebesar 3532, dimana pada garis kontinum menunjukan dalam kategori baik dan berada pada rentang nilai antara 3400-4200.

Dari hasil analisis data terlihat bahwa partisipasi masyarakat Desa Ciburial dalam program pengembangan desa wisata tinggi. dan yang mendapatkan skor tertingi yaitu pada partisipasi dalam perencanaan program 
pengembangan desa wisata. Dalam sub variabel partisipasi dalam perencanaan terdapat 5 pertanyaan yaitu :

1. Partisipasi masyarakat dalam proses perencanaan dan pengelolaan Desa Wisata Ciburial, seperti mengikuti rapat di desa. Masyarakat selalu diikutsertakan ke dalam proses perencanaan kawasan wisata seperti jika ada rapat desa mengenai program yang akan di adakan di desa wisata, atau pun mengemukakan pendapat untuk pengembangan desa wisata selanjutnya. Sehingga program pemerintah akan sejalan dengan apa yang di inginkan oleh masyarakat desa

2. Partisipasi masyarakat dalam proses pengambilan keputusan di Desa Wisata Ciburial. Masyarakat diikutsertakan ke dalam proses perencanaan pengambilan keputusan seperti akan di adakannya program prmbangunan desa untuk pembuatan objek wisata di Desa Wisata Ciburial, masyarakat harus dilibatkan untuk pengambilan keputusan ini jangan sampai ada kesalahfahaman antara stakeholder dan masyarakat setempat, harus ada timbal balik kepada masyarakat.

3. Partisipasi masyarakat dalam pembangunan sarana dan prasarana di Desa Wisata Ciburial. Masyarakat harus dilibatkan dalam program pembangunan sarana dan prasarana yang akan di buat di Desa Wisata Ciburial, jika perlu mereka diikutsertakan untuk membantu secara langsung maupun tidak langsung, secara langsung misalnya saja membantu menjadi kuli bangunan, memasak makanan untuk pekerja, menyiapkan air minum atau yang tidak langsung menyumbang dana dan lain sebagainnya.

4. Partisipasi masyarakat dalam proses kebersihan Desa Wisata di Ciburial. Masyarakat harus terlibat dalam proses kebersihan yang ada di Desa Wisata Ciburial, karena kebersihan suatu tempat akan sangat penting mengingat akan banyaknya wisatawan dan berkunjung ke Desa Wisata Ciburial. Maka dari itu, masyarakat harus ikut bekerjasama membersihkan desa dengan cara mengadakan program jumat bersih, atau gerakan pungut sampah secara berkesinambungan

5. Partisipasi masyarakat dalam kegiatan pertemuan yang di adakan di kantor Kepala Desa Ciburial. Masyarakat harus diikutsertakan dalam setiap kegiatan pertemuan yang di adakan di kantor desa. Baik itu saat rapat ataupun acara-acara lain yang sifatnya perkumpulan atau silaturahmi, hal ini dilakukan agar tidak ada hilang komunikasi antara aparat pemerintah dan masyarakat.

\section{Pengaruh Persepsi Terhadap Partisipasi Masyarakat dalam Program Pengembangan Desa Wisata di Ciburial}

\section{a. Uji Normalitas}

Berdasarkan hasil uji normalitas data dengan menggunakan program software SPSS versi 20.0, diperoleh hasil sebagai berikut: 


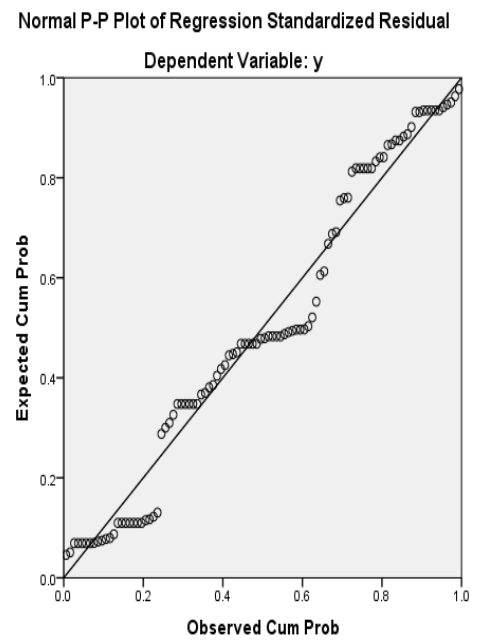

pengujian regresi linier sederhana.
Sumber: Hasil Olahan Menggunakan SPSS Versi 20.0, (2016)

Berdasarkan hasil uji normalitas pada hasil Uji Kolmogorov-Smirnov untuk variabel Persepsi (X) dan variabel Partisipasi (Y) memiliki nilai signifikansi Asymp. Sig. (2-tailed) sebesar 0,130 dimana 0,130 >0.05. Karena Asymp Sig. yang dihasilkan lebih dari 0,05, dimana syarat suatu data berada pada distribusi normal adalah $p$-value $>0.05$. Maka dapat dinyatakan data berdistribusi normal dan memenuhi persyaratan untuk dilakukan

\section{b. Uji Heteroskedastisitas}

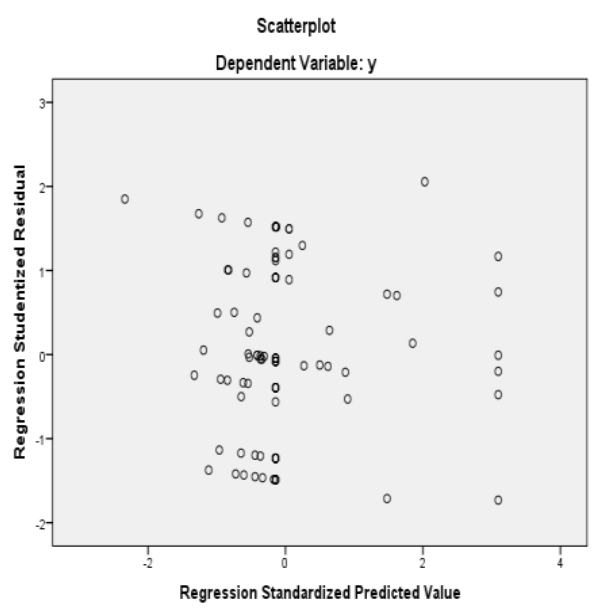

Sumber: Hasil Olahan Menggunakan SPSS Versi 20.0, (2016)

Berdasarkan hasil output pada gambar diatas terlihat bahwa titik-titik menyebar dan tidak membentuk suatu pola tertentu yang jelas. Sehingga dapat disimpulkan bahwa tidak terjadi masalah heterokedastisitas dan memenuhi syarat untuk dilakukan pengujian berikutnya yaitu regresi linier sederhana

\section{c. Uji Multikolieniritas}

\section{Coefficients $^{\mathrm{a}}$}

\begin{tabular}{|c|c|c|c|c|c|c|c|c|}
\hline \multirow{2}{*}{\multicolumn{2}{|c|}{ Model }} & \multicolumn{2}{|c|}{$\begin{array}{l}\text { Unstandardized } \\
\text { Coefficients }\end{array}$} & \multirow{2}{*}{$\begin{array}{c}\text { Standardized } \\
\text { Coefficients }\end{array}$} & \multirow[t]{2}{*}{$\mathrm{T}$} & \multirow[t]{2}{*}{ Sig. } & \multicolumn{2}{|c|}{$\begin{array}{l}\text { Collinearity } \\
\text { Statistics }\end{array}$} \\
\hline & & B & Std. Error & & & & Tolerance & VIF \\
\hline 1 & (Constant) & 19.015 & 3.547 & & 5.360 & .000 & & \\
\hline
\end{tabular}

Sumber: Hasil Olahan Menggunakan SPSS Versi 20.0, (2016) 


\begin{tabular}{|c|c|c|c|c|c|c|c|}
\hline $\begin{array}{l}\text { Persepsi } \\
(\mathrm{x})\end{array}$ & .086 & .068 & .126 & 1.254 & .213 & 1.000 & 1.000 \\
\hline
\end{tabular}

a. Dependent Variable: (y)partisipasi

Berdasarkan hasil pengujian menggunakan aplikasi SPSS ver 20 pada tabel diatas, maka dapat disimpulkan bahwa: Pemahaman mengenai persepsi tidak terjadi gejala multikolinieritas karena nilai tolerance lebih besar dari 0,10 yaitu sebesar 1,000 dan nilai VIF lebih kecil dari 10 yaitu 1,000. Berdasarkan hasil perhitungan, di peroleh nilai value Sig seluruh variabel nilai tolerance lebih besar dari 0,10 dan nilai VIF lebih kecil dari 10,00. Hal ini menunjukkan bahwa antar variabel tidak terjadi hubungan atau tidak terjadi gejala multikolinieritas.

\section{d. Uji Autokorelasi}

Model Summary ${ }^{b}$

\begin{tabular}{|l|c|r|r|r|r|}
\hline Model & $\mathrm{R}$ & $\mathrm{R}$ Square & Adjusted R Square & Std. Error of the Estimate & Durbin-Watson \\
\hline 1 & $.126^{\mathrm{a}}$ & .016 & .006 & 6.025 & 2.629 \\
\hline
\end{tabular}

a. Predictors: (Constant), persepsi (x)

b. Dependent Variable: partisipasi (y)

Sumber: Hasil Olahan Menggunakan SPSS Versi 20.0, (2016)

Nilai Durbin-Watson yang dihasilkan diatas ialah sebesar 2,629, nilai tersebut dibandingkan dengan nilai tabel signifikansi 5\% jumlah sampel 100 (n) dan jumlah variabel independen $1(\mathrm{k}=1)$ maka diperoleh nilai du 1,694. Nilai Durbin-Watson sebesar 2,629 lebih besar dari batas atas (du) yakni 1,694 dan kurang dari $4-\mathrm{du}=4-1,694=2.306$ sehingga dapat disimpulkan bahwa tidak terdapat autokorelasi.

\section{Analisis Regresi Linier Sederhana}

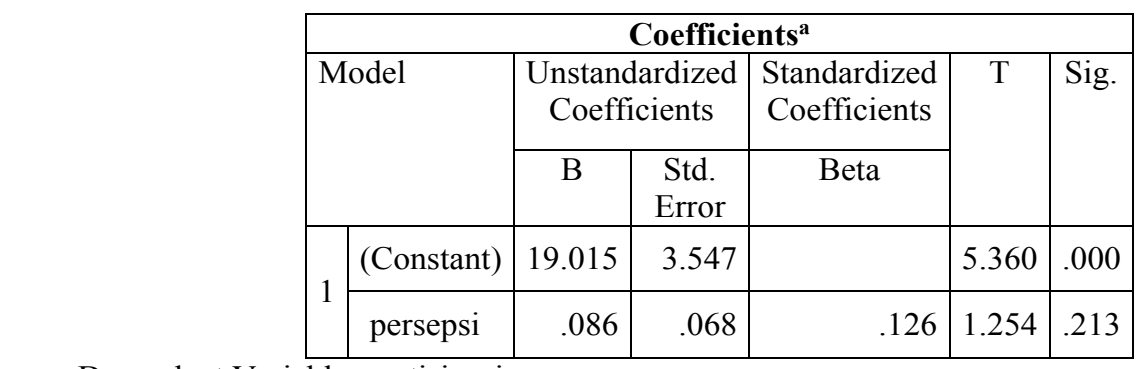

a. Dependent Variable: partisipasi

Sumber: Hasil Olahan Menggunakan SPSS Versi 20.0, (2016)

Dari hasil perhitungan yang ditampilkan pada output table regresi linier sederhana maka diperoleh model regresi sebagai berikut :

$\mathrm{Y}=19,015+0,086 \mathrm{X}$

Berdasarkan persamaan di atas, diketahui bahwa nilai konstanta a memiliki arti bahwa persepsi (x) bernilai 0,213 atau partisipsi masyarakat dipengaruhi oleh persepsi maka nilai konsanta 19.015 sedangkan koefisien regresi $\mathrm{b}$ bernilai 0,086 yang memiliki arti bahwa jika variable persepsi (x) meningkat sebesar satu satuan, maka partisipasi akan naik sebesar 0,086. Koefisien regresi tersebut bernilai positif. 


\section{a. Uji Koefisien Determinasi}

Model Summary

\begin{tabular}{|l|c|r|r|r|r|}
\hline Model & $\mathrm{R}$ & R Square & Adjusted R Square & Std. Error of the Estimate & Durbin-Watson \\
\hline 1 & $.126^{\mathrm{a}}$ & .016 & .006 & 6.025 & 2.629 \\
\hline
\end{tabular}

a. Predictors: (Constant), persepsi (x)

b.Dependent Variable: partisipasi (y)

Sumber: Hasil Olahan Menggunakan SPSS Versi 20.0, (2016)

$$
\begin{aligned}
K D \quad & =r^{2} \times 100 \\
& =(0,126)^{2} \times 100 \% \\
& =0,16 \%
\end{aligned}
$$

Koefisien determinasi dari hasil perhitungan di atas diperoleh persentase sebesar $0,16 \%$ maka hal ini menunjukan bahwa persepsi masyarakat memberikan kontribusi sebesar $0,16 \%$ terhadap partisipasi masyarakati Ini berbanding lurus dengan teori yang mengatkan bahwa persepsi berpengaruh terhadap partisipasi. Uji determinasi di atas menghasilkan angka yang kecil karena hanya satu variable $\mathrm{x}$ yang di teliti, sehingga model ini tidak terlalu berdampak pada penelitian karena $r$ square tidak termasuk uji statistik yang hanya digunakan untuk mengoptimalkan model regresi. Sehingga untuk melihat pengraruh persepsi terhadap partisipasi sudah bisa diwakilkan oleh uji hipotesis. Hal ini juga dapat terjadi karena kurangnya variasi yang disebabkan oleh perbedaan pemahaman infrasruktur dan perbedaan pemahaman responden dalam menangkap maksud item pertanyaann dalam kuisioner. Sehingga, 99,14\% disebabkan oleh faktor lain yang tidak diteliti.

\begin{tabular}{|c|c|c|c|c|c|}
\hline \multirow[t]{2}{*}{ Model } & \multicolumn{2}{|c|}{ Unstandardized Coefficients } & \multirow{2}{*}{$\begin{array}{c}\text { Standardized Coefficients } \\
\text { Beta }\end{array}$} & \multirow[t]{2}{*}{$\mathrm{t}$} & \multirow[t]{2}{*}{ Sig } \\
\hline & B & Std. Error & & & \\
\hline (Constant) & 19,015 & 3,547 & & 5,360 & ,000 \\
\hline$x$ & ,086 & ,068 & ,126 & 1,254 & ,213 \\
\hline
\end{tabular}

\section{b. Uji Hipotesis}

\section{Coefficients $^{\mathrm{a}}$}

a. Dependent Variable: $\mathrm{y}$

Sumber: Hasil Olahan Menggunakan SPSS Versi 20.0, (2016)

Untuk menentukan angka tabel peneliti menentukan tingkat signifikan sebesar $10 \%$ atau $\alpha=0,1$ dengan probabilitas dua arah. Sedangkan untuk penentuan angka derajat bebas atau degree offreedom (df) dengan rumus berikut: Keterangan :

df $\quad=$ Degree of Freedom

$\mathrm{n} \quad=$ Jumlah Responden

$\mathrm{k}=$ Jumlah Variabel (Bebas dan Terikat)

$$
\mathbf{d f}=\mathbf{n}-\mathbf{k}
$$


Berikut merupakan hasil besaran derajat bebas:

$$
\mathrm{df}=100-3
$$

df $=97$

Dengan demikian, tabel dalam penelitian ini yaitu sebesar 1,661. Maka dapat diketahui bahwa 5,360 > 1,661 sehingga dapat dipastikan bahwa thitung $>$ tabel. Maka oleh karena itu dapat diketahui bahwa $\mathrm{H}_{0}$ ditolak dan $\mathrm{H}_{1}$ diterima atau dapat diartikan adanya pengaruh antara persepsi masyarakat terhadap partisipasi.

\section{PEMBAHASAN}

Dari hasil pengujian regresi sederhan maka dapat di tarik kesimpulan bahwa berdasarkan nilai konsanta 19.015 sedangkan koefisien regresi b bernilai 0,086 yang memiliki arti bahwa jika variable persepsi $(\mathrm{x})$ meningkat sebesar satu satuan, maka partisipasi akan naik sebesar 0,086. Sehingga jika persepsi masyarakat terhadap suatu persoalan meningkat maka partisipasi untuk mengikuti suatu kegiatan akan meningkat pula sebesar 0,086. Persepsi disini yaitu persepsi masyarakat terhadap keberadaan Desa Wisata Ciburial, dan partisipasinya terhadap pengelolaan desa wisata tersebut.

Untuk hasil uji koefisien determinasi dapat di tarik kesimpulan bahwa persepsi masyarakat memberikan kontribusi sebesar $0,16 \%$ hal ini terjadi karena beberapa faktor diantaranya penyebaran kuisioner yang kurang heterogen dan kurang variatif, penyebaran kuisioner banyak berpusat kepada orang-orang yang mengerti akan keberadaan pariwisata di desanya. Sehingga hasil yang didapat tidak terlalu banyak informasi data.

Dalam penelitian yang di lakukan sebelumnya menghasilkan bahwa persepsi masyarakat mengenai keberadaan desa wisata tidak begitu baik hal ini disebabkan oleh faktor internal dan eksternal seperti dari masyarakatnya sendiri yang pendidikanya rendah dan pengetahuan akan pariwisatanya masih kurang, fokus pemerintah terhadap pengembangan desa masih belum menyebar. Setelah dilakukan penelitian lebih lanjut, terdapat perubahan persepsi dari masyarakat Desa Ciburial terkait pengembangan desa wisata kearah yang lebih baik. Yang semula persepsi masyarakat kurang terhadap desa wisata, sekarang mereka sudah mulai memahami mengenai dampak positif yang dihasilkan dari berkembangnya desa wisata. dari variabel yang dijelaskan, pengaruh persepsi terhadap partisipasi disini hanya mampu menjelaskan $0,16 \%$ sehingga banyak faktor lain selain persepsi yang menyebabkan partisipasi masyarakat tinggi

Contoh lain mengenai persepsi berpengaruh terhadap partisiasi yang ada di masyarakat yaitu sering dilandasi oleh persepsi yang kurang positif. Maka keterlibatan yang ada sering merupakan partisipasi semu. Keadaan seperti itu bila sering terjadi maka akan berakibat kurang lancarnya kegiatan sesuai dengan rencana sebelumnya sehingga menyulitkan usaha pencapaian suatu tujuan program secara utuh (Sutopo, 1996. Hml : 132). Tetapi keadaan akan berubah sebaliknya, yaitu jika persepsi masyarakat positif untuk semua kegiatan yang ada 
di desa wisata, maka keinginan masyarakat untuk ikut berpartisipasi pun semakin tinggi. Dari teori di atas sangat jelas bahwa persepsi berpengaruh terhadap partisipasi masyarakat kedepannya karena hasil yang di dapatkan dari data kuisioner ialah nilai dari persepsi itu tinggi sehingga nilai dari partisipasi masyarakat juga tinggi. Persepsi masyarakat Desa Ciburial meningkat karena adanya bentuk upaya yang dilakukan oleh pemerintah desa terkait penyuluhan pariwisata. Bentuk-bentuk penyuluhan yang dilakukan seperti adanya mojang jajaka Kabupaten Bandung yang datang dan memberikan pemahaman kepada masyarakat sekitar desa terkait pariwisata dan desa wisata. Selain itu, terbentuknya KOMPEPAR juga membantu terbentuknya persepsi masyarakat terkait pariwisata dengan adanya kegiatan-kegiatan wisata yang digagas oleh KOMPEPAR setempat. Dampak positif yang dirasakan masyarakat dari adanya pariwisata tersebut misalnya bertambahnya mata pencaharian masyarakat, terbentuknya interaksi antara masyarakat dan wisatawan yang datang serta adanya pendapatan yang dapat menguntungkan masyarakat dari segi ekonomi. Persepsi dapat mempengaruhi secara berbanding lurus terhadap partisipasi karena semakin masyarakat memahami hal-hal atau dampak positif yang diberikan dari adanya parwisata dan perubahan desa menjadi desa wisata maka akan semakin tinggi pula keinginan mayarakat untuk turut berkontribusi terhadap desa. Karena tidak hanya memberikan kontribusi keterlibatan atau partisipasi masyarakat dapat memberikan dampak positif bagi masyarakat itu sendiri.

\section{SIMPULAN}

Berdasarkan hasil analisis dan pengumpulan data yang telah di uraikan di bab sebelumnya mengenai pengaruh persepsi masyarakat terhadap partisipasi dalam program pengembangan di Desa Wisata Ciburial, yang mengacu pada rumusan masalah yang telah dirumuskan sebelumnya, di dapatkan kesimpulan antara lain:

1. Pemahaman masyarakat mengenai desa wisata tergolong cukup tinggi, artinya mereka mengerti dan cukup memahami apa itu desa wisata dan tujuan di buatnya desa wisata di desa mereka. Dari hasil penelitian tersebut dapat disimpulkan bahwa persepsi masyarakat dalam pengembangan desa tergolong memiliki respon baik, hal ini dapat dilihat dari setiap butir pertanyaan yang memiliki skor tinggi dan persepsi masyarakat mengenai persepsi desa wisata juga baik. Masyarakat cukup antusias terhadap pengembangan desa wisata yang dilakukan di desa mereka. Dengan begitu, ini akan memudahkan pengelola untuk terus mengembangkan desa wisata ke arah yang lebih baik bersama dengan keterlibatan masyarakat di dalamnya.

2. Data yang didapat dari variabel partisipasi masyarakat dengan indikator partisipasi dalam tahap perencanaan berdasarkan rekapitulasi tanggapan 
responden mengenai partisipasi masyarakat dalam program pengembangan desa wisata, skor tertinggi diperoleh dari sub variabel partisipasi dalam perencanaan program pengembangan desa wisata, sedangkan skor terendah di peroleh dengan sub variabel partisipasi dalam pemanfaatan hasil dan evaluasi pengembangan desa wisata. Dapat dilihat juga pada hasil penelitian dimana pada garis kontinum menunjukan dalam kategori baik. Dari hasil analisis data terlihat bahwa partisipasi masyarakat Desa Ciburial dalam program pengembangan desa wisata tinggi. Artinya masyarakat harus selalu dilibatkan dalam proses pengelolaan dan pengambangan desa karena seluruh aspek kegiatan wisata yang ada di Desa Ciburial berada di tanah masyarakat.

3. Persepsi terhadap partisipasi masyarakat dalam program pengembangan desa wisata memiliki hubungan yang sangat kuat serta signifikan hal ini dapat dilihat dari setiap pengujian data yang hasilnya selalu positif, pengaruh persepsi terhadap partisipasi disini hanya mampu menjelaskan $0,16 \%$ sehingga banyak faktor lain selain persepsi yang menyebabkan partisipasi masyarakat tinggi. Yaitu bisa dari faktor internal atau faktor eksternal. Dapat di tarik kesimpulan bahwa persepsi akan mempengaruhi masyarakat dalam hal mengambil keputusan, entah itu keputusan untuk ikut berpartisipasi atau pun sebaliknya.

\section{DAFTAR PUSTAKA}

Hadiwijoyo, S. 2012. Perencanaan Pariwisata Pedesaan Berbasis Masyarakat (Sebuah Pendekatan Konsep). Yogyakarta : Graha Ilmu

Laksana, N. S. 2013. Bentuk - Bentuk Partisipasi Masyarakat Desa dalam Program Desa Siaga Di Desa Bandung Kecamatan Playen Kabupaten Gunung Kidul Provinsi Daerah Istimewa Yogyakarta. 1, (1), 56-66.

Sevilla, C. G. et. Al. 2007. Research Methods. Quezon City : Rex Printing Company.

Sugiyono. 2012. Metode Penelitian Kombinasi (Mixed Methods). Bandung : Alfabeta

\section{Sumber Internet}

Badan Pusat Statistik Kota Bandung. http://bandungkota.bps.go.id/. Diakses April 2016.

Data mengenai Desa Wisata Ciburial. Wordpress Ciburial. Diakses April 2016 